\title{
Assessment of Tendering Methods on the Successful Implementation of Constituency Development Fund Projects in Njoro Sub-County, Nakuru Kenya
}

\author{
Rotich Moses Amdany ${ }^{1}$, Dr. Josephat Kwasira ${ }^{2}$ \\ ${ }^{1,2}$ Department of Entrepreneurship, Procurement and Management, Jomo Kenyatta University of Agriculture and Technology, Juja, Kenya
}

\begin{abstract}
The complexities of public procurement performance require more than just a mere policy framework in every nation. There is need to have direct interventions that would undo the complexities that bedevil the efforts of the government and international organization for supporting the public procurement performance initiatives. In this era of dynamic and frequently changing corporate environment, purchasing managers are encouraged to be proactive. This study sought to examine in detail the influence that procurement practices has on the successful implementation of Constituency Development Fund (CDF) projects in Njoro Sub-county. There have been numerous reports by scholars, professionals, the media and civil rights organizations that the whole CDF ideology is being used as a tool for embezzlement of public funds as opposed to it being a devolved development vehicle; part of the cited malpractice area is in the entire procurement process of the projects" materials, goods and services. In the public sector, procurement is highly unsatisfactory with numerous cases of corrupt activities including collusion of some CDF Committee members being suppliers, which raises the question of conflict of interest. There is also the aspect of poor entrepreneurial attitude by the Small and Medium Enterprises (SME) who are supposed to be promoted by supplying to the CDF projects but majority lack the ethics to pay taxes or even be registered in order for Constituency Development Fund Committee (CDFC) to contract them within law. The specific objectives of the study were To assess how procurement committee affects the performance of Constituency development funds projects, how tendering procedures affects the performance of Constituency development funds projects and how monitoring of procurement procedures affects the performance of constituency development fund projects. The general objective of the study was to assess the influence of procurement process on the performance of Constituency Development Fund Projects in Njoro Sub County Nakuru. Descriptive research design was adopted for this study and the target population consisted of CDF committee members in various projects in Njoro constituency. The total population was 170 individuals from CDF committee members and a representative sample of 93 respondents selected and drawn from the various project categories funded by CDF including Education, Health, Water and roads. Data was collected using questionnaires and was tested for reliability by use of pilot study where the respondents were drawn outside the selected pilot units. The pilot data was not used in the actual analysis and thus did not influence the outcomes of the data. After data was collected the questionnaires were edited for correction and then the data cleaned, coded and analyzed using SPSS version 20. Both descriptive and inferential statistics (correlation analysis) were used to analyze the data and the findings were presented in tables. The correlation results depicted positive relationships between tendering methods and successful implementation of Constituency Development Fund Projects in Njoro Sub-County.
\end{abstract}

Keywords: Tendering, Open tendering, Restricted tendering, Direct tendering, Constituency Development Fund and CDF Project Implementation

\section{Introduction}

\subsection{Background of the study}

Constituency Development Fund was established with the aim of improving service delivery to constituents, alleviating poverty, enhancing economic governance and ultimately contributing to socio-economic development. Under the CDF Act, an amount not less than $2.5 \%$ of governmentes annual revenue is set aside for the fund (Oyugi, 2006). The fund was designed to support constituency-level, grass-root development projects. It was aimed to achieve equitable distribution of development resources across regions and to control imbalances in regional development brought about by partisan politics. It targeted all constituency-level development projects, particularly those aiming to combat poverty at the grassroots. Jerry (2006) points out that the CDF program has facilitated the putting up of new water, health and education facilities in all parts of the country, including remote areas that were usually overlooked during funds allocation in national budgets.

Procurement is the acquisition of goods, services or works from an external source. It is favorable that the goods, services or works are appropriate and that they are procured at the best possible cost to meet the needs of the acquirer in terms of quality and quantity, time, and location (Weele, 2010). Corporations and public bodies often define processes intended to promote fair and open competition for their business while minimizing exposure to fraud and collusion. Almost all purchasing decisions include factors such as delivery and handling, marginal benefit, and price fluctuations. Procurement generally involves making buying decisions under conditions of scarcity. If good data is available, it is good practice to make use of economic analysis methods such as cost-benefit analysis or cost-utility analysis. An important distinction should be made between analyses without risk and those with risk. Where risk is 


\section{International Journal of Science and Research (IJSR) \\ ISSN (Online): 2319-7064 \\ Index Copernicus Value (2013): 6.14 | Impact Factor (2015): 6.391}

involved, either in the costs or the benefits, the concept of expected value may be employed.

Based on the consumption purposes of the acquired goods and services, procurement activities are often split into two distinct categories. The first category being direct, production-related procurement and the second being indirect, non-production-related procurement (Lewis, 2009). Direct procurement occurs in manufacturing settings only. It encompasses all items that are part of finished products, such as raw material, components and parts.

A tender is refers to a process of submission made by a prospective supplier in response to an invitation to make an offer for the supply of goods or services. In construction, the main tendering process is generally undertaken for the selection of the contractor that will construct the works or undertake projects funded by the government. In this case, the process of selection of a bidder can take different tendering methods including; open tendering, selective tendering, negotiated tendering, serial tendering, framework tendering as well as single-stage and two-stage tendering. In this study, the researcher considers three main tendering methods adopted in the implementation of CDF projects in Njoro Sub-county, Nakuru County-Kenya. The three main tendering methods used in this case include open tendering, restricted tendering and direct tendering methods. These three tendering methods are frequently used in selection and award of tenders to successful bidders to implement CDF projects which are classified depending on the respective sectors such as health sector (hospitals and dispensaries), education sector (primary and secondary schools) and transport sector (roads).

The Constituency Development Fund (CDF) was established in 2003 through an Act of Parliament as detailed in The Kenya Gazette Supplement No. 107 (Act No. 11) of 9th January 2004 (RoK, 2012). The Act was amended through the CDF (Amendment) Bill, 2007 in the Kenya Gazette Supplement No. 112 (Act No. 16). The fund aims to control imbalances in regional development brought about by partisan and sectarian politics. The Constituency Development Fund (CDF) was an initiative to combat poverty and promote equitable growth and development around the country leading to achievement of Vision 2030.

It targets all constituency-level development projects, particularly aimed at combating poverty at the grassroots. The fund comprises an annual budgetary allocation equivalent to $2.5 \%$ of the government's ordinary revenue. A motion has been sponsored and discussed in parliament seeking to increase this allocation to $7.5 \%$ of government revenue. $75 \%$ of the fund is allocated equally amongst all the current 210 constituencies. The remaining 25\% is allocated as per constituency poverty level. A maximum per centum of each constituencyes annual allocation may be used for other projects as follows: 5\% emergency funds, 15\% education bursaries, $2 \%$ monitoring and evaluation of projects, $3 \%$ recurrent expenses, $2 \%$ sports, $2 \%$ environment and $3 \%$ administration. The CDF core values include: Transparency, Accountability, Equity in resource distribution and Participatory approaches by all stakeholders.
Constituency development fund scheme is regarded as the most effective way of equitable distribution of national resources throughout the country from the consolidated fund based on the ministry of finance report (2010). The Constituency development fund replaced the district focus for rural development and the harambee projects. In effect, CDF funding is part of a wider approach in building socialeconomy in Kenya, by taking off from a holistic understanding of what human development is all about and by suggesting a comprehensive, innovative, institutional and legal framework for socially-inclusive local economic and community development (Gituto, 2007).

According to Chandra (2008), a project is an investment activity that involves a current or future outlay of funds in the expectation of a stream of benefits extending far into the future. A public project is therefore one where such an investment involves the use of public funds by a Government body mandated to carry out certain specific missions to achieve specific objectives for the benefit of the greater public majority. The complexities of public procurement performance require more than just a mere policy framework in every nation. There is need to have direct interventions that would undo the complexities that bedevil the efforts of the government and international organization for supporting the public procurement performance initiatives. In this era of too quickly changing corporate environment, purchasing managers are encouraged to be proactive. Purchasing managers need to develop a more proactive strategic approach and encourage a proactive approach to purchasing planning (Rajagopal \& Bernard, 1993).

\subsection{Statement of the Problem}

The main core objectives of establishing constituency development fund, was to eradicate poverty in the grass root level throughout the country, however there is stern outcry that poverty levels have increased instead. According to Wanjiru (2008) poverty levels have increased from 56\% in 2002 to $60 \%$ in 2008, public service delivery has failed, inequalities in resource distribution prevails and funds meant for community use have been looted by corrupt civil servants and politicians. A new audit carried out by the National Taxpayers Association (NTA) reveals that Sh242 million of the Sh1.2 billion allocated to the Development Fund (CDF) in the period 2010/2011 is either misappropriated or unaccounted for. The audit, carried out in 28 counties, reveals that of the Shs242 million, Sh179.1 million was lost on shoddy projects, some of which are complete while others remain incomplete but KShs40.5 million was unaccounted for, and KShs22.2 million was spent on projects that have been abandoned. Njoro Constituency was ranked among the worst constituencies among the surveyed constituencies in the management for CDF funds.

A total of Kshs. 226,732,369 has been allocated to the constituency since 2003/2004 - 2009/2010. 39\% of the total CDF funds allocated to the monitored projects in FY 2009/2010 are on abandoned projects while KShs.58.9 million of the Sh. 72.5 (81.2\% of funds) allocated for Marakwet East Constituency having been mismanaged. NACCSC (2008) shows that many constituents feel resources

\section{Volume 5 Issue 4, April 2016}




\section{International Journal of Science and Research (IJSR) \\ ISSN (Online): 2319-7064}

Index Copernicus Value (2013): 6.14 | Impact Factor (2015): 6.391

are not flowing to the intended beneficiaries, primarily as the result of improper influence by the MP. Constituent perceptions on how CDF resources were allocated led to a situation where the majority of respondents felt that the MP favored people of his or her ethnic group/clan/community or allocates more resources to the region where the MP comes from (NACCSC, 2011).

It is evident that CDF money is not managed in a transparent manner and that communities are not sufficiently involved in its management leading to loss of funds, numerous incomplete projects, low quality and irrelevant project across the constituencies in the country. The study on the level of participation in project identification and by constituents a case of Makadara Constituency CDF while studied the influence of constituency development funded projects in selected indicators of poverty reduction in Kitutu Masaba Constituency. However the authors have not indicated to us how procurement process is done within the constituency and its contribution to the performance of the same. The study will therefore be conducted to find out the influence of tendering methods on performance of constituency development fund projects in Kenya with reference to Njoro Sub County Nakuru.

\subsection{Objectives of the Study}

1)To establish the roles played by open tendering method, on the successful implementation of constituency development funds projects in Njoro Sub-County.

2)To analyze the role played by restricted tendering method on the successful implementation of constituency development funds project in Njoro Sub-County.

3)To identify the role played by the direct tendering method on the successful implementation of the constituency development funds projects in Njoro Sub-County.

\subsection{Research Questions}

1)How does an open tendering method influence the successful implementation of constituency development fund projects in Njoro Sub County?

2)How does restricted method affect the successful implementation of constituency development funds projects in Njoro Sub County?

3) How does direct tendering method affects the successful implementation of Constituency development funds projects in Njoro Sub County?

\section{Literature Review}

\subsection{Theoretical Review}

The sub section expounds on the major theories underpinning the study. The theories offer a base for the conceptualization of the variables under study. The study will major on the theories including the theory of core competencies, Transactional cost theory and Relational Exchange theory. On the basis of their applicability to this study, these theories seek to enhance a thorough understanding of how tendering methods influence the performance of Constituency Development Fund projects in Njoro sub-county, Nakuru.

\subsubsection{Theory of Core Competencies}

Core competencies theory was coined by leading management experts C. K. Prahalad \& Gary Hamel (1990) as a theory of strategy that prescribes actions to be undertaken by organizations to achieve competitive advantage. With regards to tendering for government funded projects, the theory suggests activities should be performed either in house or by suppliers. Hancox \& Hackney (2000) opine that activities which are not part of the organiztions ${ }^{\text {ce }}$ core competencies, should be outsourced with best-in-the-world suppliers. However, some non-core activities may have to be retained in house if they are part of a defensive posture to protect competitive advantage. The concept of core competency states that firms must play to their strengths or those areas or functions in which they have competencies. In addition, the theory also defines what forms a core competency and this is to do with it being not easy for competitors to imitate, it can be reused across the markets that the firm caters to and the products it makes, and it must add value to the end user or the consumers who get benefit from it. Although some authors indicate characteristics of core competencies, most of the literature on this subject seems tautological - core equals key or critical or fundamental. Employees in non-core functions (even if not facing outsourcing) may feel excluded by the organization because they are a non-dominant discipline For example, information technology employees working on web based legal services in a law firm may feel excluded by lawyers in the firm. In the public sector, there may be particular uncertainty about what is core; and it has been suggested that government may aim to discover its core competencies via a residualisation process - outsourcing until and unless the shoe pinches, or a political backlash is triggered (Hancox \& Hackney, 2000).

An organization may view IT itself as a core competence. It seems that most successful companies have a good understanding of IT's potential. However, some organizations outsource IT even though they see it as core and delivering competitive advantage. This may be because IT can be considered core at the corporate level, but some of its aspects, at lower levels, might be commodities. Thus, the complexity of IT, and its core nature, may make the contracting out of IT a particularly challenging exercise. The ability to define IT requirements and to monitor their delivery by third parties may be some of the core IT competencies that any organization must have if it is to outsource IT successfully. This theory applies to this study as it recognizes that in some instances, tendering process and the appropriate tendering method applied by an organization must be based on the core competencies required of the bidders to ensure an effective tendering for successful implementation of Projects (Chandra \& Kumar, 2000). In other words, organizations must orient their strategies to tap into the core competencies as a fundamental basis for the value addition and customer preference. 


\section{International Journal of Science and Research (IJSR) \\ ISSN (Online): 2319-7064}

Index Copernicus Value (2013): 6.14 | Impact Factor (2015): 6.391

\subsubsection{Transaction cost Theory}

Transaction Cost theory was developed by Williamson (1979) as a theory accounting for the actual cost of outsourcing production of products or services. According to Williamson (1979) the actual transaction costs are considered in when making critical decisions in an organization. This theory finds application in this study as it pinpoints the underpinnings of decisions relating to sourcing of materials and services necessary for implementation of projects. With regards to tendering for CDF projects, transaction costs arise because complete contracting is often impossible, and incomplete contracts give rise to subsequent renegotiations when the balance of power between the transacting parties shifts (Williamson, 1979). Five attributes of business exchange are positively associated with transaction costs: the necessity of investments in durable, specific assets; infrequency of transacting; task complexity and uncertainty; difficulty in measuring task performance; and interdependence with other transactions.

The necessity of early investments in durable, transactionsspecific assets (e.g. human and physical capital) shifts the balance of power between transaction participants, because in later renegotiations these costs are sunk costs of the party that incurs them. Infrequent transactions increase the likelihood of opportunistic behavior in later periods by reducing the threat of retribution. In situations where broader market reputations are at stake, infrequent transactions may be sustainable. However, even long-term contracts often do not provide sufficient adaptation mechanisms, and inflexibility may actually induce holdup. The five transaction attributes indicate settings in which opportunistic behavior is likely. If transactions costs offset production cost advantages of the external supplier, the firm subsumes the activity -an outcome termed vertical integration or in-sourcing.

Drawing on transaction cost economics theory, the sourcing decision is often seen as a rational decision made by firms that have considered transaction related factors such as asset specificity, environmental uncertainty, and other types of transaction costs (Ang \& Straub, 1998). Whenever an activity is conducted under conditions of high uncertainty, or whenever an activity requires specific assets, transaction costs, the costs of writing, monitoring and enforcing contracts, are likely to be high. When transaction costs are high, outsourcing is deemed to be relatively inefficient compared with internal, hierarchical administration.

\subsubsection{Relational Exchange Theory}

Relational exchange theory is based on relational norms. According to this theory, the key to determining how efficiently contract governance is carried out lies in the relational norms between the transactors. For example, the degree to which transactors engage in joint planning or their extent of inter-firm information sharing, is process elements that determine the costs associated with periodically renegotiating contracts. Those transactors who have established behavioral norms that can simplify and smooth the renegotiation process can reasonably expect to incur lower ex post bargaining costs than those who have not (Artz \& Brush, 2000). Many classifications of norms have been proposed, but no one is regarded as dominant. It has been proposed that relational norms are a higher order construct consisting of three dimensions (Kern \& Blois, 2002). First, is flexibility, which defines a bilateral expectation of the willingness to make adaptations as circumstances change. Second, is information exchange, which defines a bilateral expectation that parties will proactively provide information useful to the partner. And third, is solidarity, which defines a bilateral expectation that a high value is placed on the relationship. It prescribes behaviors directed specifically towards relationship maintenance.

\subsection{Empirical Review}

In tandem with the specific study objectives, this section reviews literature relating to the three specific objectives as conceptualized into independent variables and one dependent variable. The independent and dependent variable were broken down into indicators. The indicators on tendering methods and successful implementation of CDF Projects are discussed in this subsection.

\subsubsection{Open Tendering Method}

According to Adedokun, Ibironke and Babatunde (2013), an open tendering method is one where a client advertises a tender in local newspapers and other technical press inviting contractors and potential suppliers to apply for tender to supply goods or provide serices required by the organization. The Open tendering Method is the preferred method of procurement and alternative procurement methods are used only if specific conditions are met. In an open tendering procedure, there is a high possibility of receiving several bidders for any given product or product category. This is because many business entities express their interests and therefore submit their bids. Handling several bid documents can be hectic and demanding. Adedokun, Ibironke, \& Babatunde (2013) opine that organizations reduce the number of tenderers by requiring a payment of nonrefundable fee which also helps the organization to recover the tender-related costs.

A study done by Adedokun, Ibironke \& Babatnde (2013) in Nigeria reveals that open tendering is often adopted by government, parastatals and other organizations which are financed by public resources. The study indicates that organizations that adopt an open tendering system have high chances of enhancing accountability and limiting instances of favouritism. Because open tendering creates room for potential suppliers and contractors to compete, it is possible for the organization to select the cheap and very economical suppliers (Adedokun, Ibironke \& Babatnde, 2013)

Open Tender Method should thus be considered as the default method when no special circumstances permit the application of restrictions to the level of competition and when the estimated value is not below the thresholds permitting the application of a restricted competition such as Request for Quotation or Restricted Tender for efficiency. If the Open Tender (Goods, Works and Services) Procurement Method is used, it should be applied in accordance with the Procurement Thresholds Matrices established for each class of Procuring Entity (Nick, Chiu \& Hung, 2007). 


\section{International Journal of Science and Research (IJSR) \\ ISSN (Online): 2319-7064 \\ Index Copernicus Value (2013): 6.14 | Impact Factor (2015): 6.391}

The procedures for applying the Open Tender Goods, works and services Procurement Method whether applying direct advertisement requirements or mo-stage tender proceedings are presented in this section. Where differences exist they are clearly pointed out and explained for ease of reference and application. In the case of doubt, the procurement officer should always refer to the Public Procurement Oversight Authority. However, this tendering method also has some limitations. Firstly, many bidders can express interest in the tender $\mathrm{b}$ submitting tender documents which have all to evaluated and analysed for their as required by the procurement laws and procedures. The process of evaluation and analysis of all the bid documents can be cumbersome, time consuming and wasteful to the construction projects as well as implementation of CDF projects. This method can as well be very costly to organizations.

The choice of the method takes into account the estimated value of procurement. This includes consideration of the desirable level of competition. Market knowledge is necessary to ensure that the level of competition is adequately appreciated. The procurement planning should have sufficient time provision to allow publication of the tender announcement and submission. Competition is thus a composite result of clarity of specifications, time and transparency of the method selected It is the responsibility of the procurement unit to ensure the selection of the most appropriate method for guaranteeing value for money.

\subsubsection{Restricted Tendering Method}

A restricted tendering method occurs in a case where only a few invited or selected contractors are allowed to bid for any available tender (Chinyio, 2011). Restricted tendering follows a two-stage process where all suppliers who have express interest in supplying a given institution are sent PreQualifying Questionnaire (Nick, Chiu \& Hung, 2007). Thereafter, the appropriate suppliers are further sent invitation to tenders whereby they are expected to respond to such communication within some specified duration. This method makes competition among suppliers lesser and so the tendering entity may not benefit on low product pricing.

However, an organization can apply this tendering method when there is need of specialized expertise or high technology (Mohammed, Hamdan, Othman \& Noor, 2010). The Restricted Tender Procurement method may be used as an alternative procurement method only as allowed by the applicable procurement Act and other Regulations. As such, for the restricted tendering method to be applied effectively, it must be provided for in the procurement plan and approved by the tender committee.

Wamae (2014) opines that the restricted tendering method applies where the procurement is complex and there is a need to restrict bidding to pre-qualified candidates. It also applies in situations where the expected bidders are very many and there is a need to restrict bidding to a manageable number and where there are only a few known bidders arid there is no advantage seen in advertising an open tender. However, a major impediment to this tendering method is that in some cases, some bidders may employ cover-pricing thereby reducing the amount of serious bids (Chinyio, 2011).

\subsubsection{Direct Tendering Method}

Recent studies indicate that the direct procurement method is not a preferred method because it completes the tendering procedure devoid of competition and transparency and so the tendering entity may fail to obtain value out of the tendering process. According to Mungai (2014) the procuring entities are therefore except when it is not avoidable and strictly in accordance with the requirements of the Act and the Regulations. When direct procurement is used it procuring entity's procurement plan and also approved by the tender committee.

Direct procurement may be used in various circumstances. Direct tendering method can be use in a myriad of different circumstances in order to procure goods and services in an economical manner. Firstly, when there is only one supplier who can supply the goods works or service being procured and there is no reasonable alternative or substitute for the goods, works or services. Direct procurement method can also be used where the goods being produced are urgent and because of the urgency the other available methods of procurement are not practical. This is the situation which can be regarded as an institutional emergency. In such cases the circumstances that gave rise to the urgency were not foreseeable and were $\mathrm{m}$ the result of dilatory conduct or negligence $m$ the part of file procuring entity.

According to the contemporary tendering practices, in situations where direct procurement is used, no thresholds are considered provide the above conditions are met and the procurement method is approved by the tender committee. Procuring entities are encouraged to have their own internal rules and procedures of including procurements considered urgent or emergencies which are to be made through direct procurement to provide for efficiency, authorization and accountability (Waara,2007; Wamae, 2014). Where direct procurement is used, proper documentation and specifications must be prepared After the bid is received from the only bidder, negotiations are allowed before the contract award is made. Contract award shall be by the tender committee or by any other authority if provided for by the internal rules and regulations of the procuring entity. Where the contract award is not by the tender committee, the contract award shall be reported to the tender committee (Wamae, 2014).

Negotiations of the contract shall be after the approval of the contract award by the tender committee. Regulation 58 (2) of the regulations provides that negotiations shall be conducted by at least two members of staff of the procuring entity appointed by the accounting officer or head of procuring entity on the recommendations of the procurement unit. Negotiations under direct procurement method may include negotiation of the price. The negotiating team shall prepare a report of the negotiations which shall be submitted to the tender committee for decision making Regulation 58(3). Regulation 62 (3) provides that a procuring entity shall, within 14 days after notification of the award of the contract, report any direct procurement of a value exceeding Ksh 500,000 to the Public Procurement Oversight Authority (PPOA).

\section{Volume 5 Issue 4, April 2016}




\section{International Journal of Science and Research (IJSR) \\ ISSN (Online): 2319-7064}

Index Copernicus Value (2013): 6.14 | Impact Factor (2015): 6.391

\subsection{Conceptual Framework}

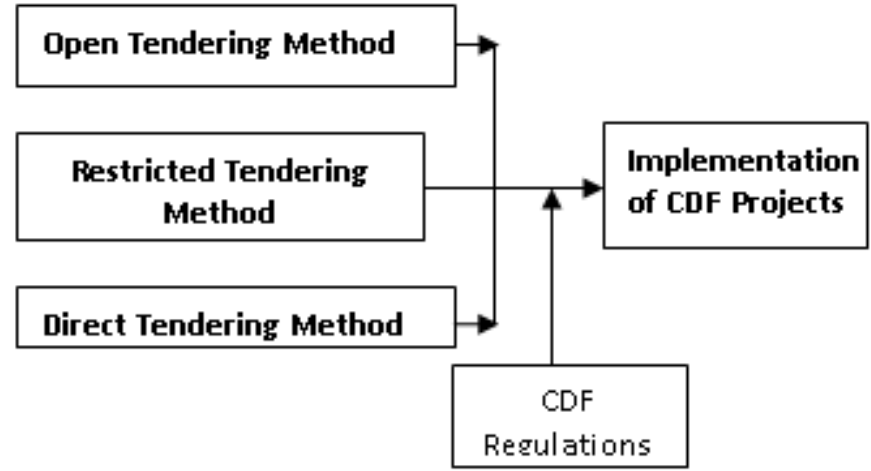

\section{Methodology}

\subsection{Research Design}

Cooper \& Schindler (2006) describe a research design as a plan and a structure of investigation concerned with finding out the what, where and how of a phenomenon as expressed in the research questions. This study adopted descriptive research design that utilized both quantitative and qualitative approaches. It was a case study of Menengai Oil Refinery.

\subsection{Population of the Study}

Target population refers to a group of members of real set persons, events or objects as to which a researcher is willing to generalize the results of the research study. Target population of the study was 172 projects with respondent being project committee members (86 from education, 56 from health sector and 30 from roads.) of projects fully funded by CDF In Njoro sub-county.

\subsection{Sample Size and Sampling Procedure}

The study used stratified sampling technique in the selection of the CDF Projects committee members, where there are 170 projects in Njoro constituency that have been funded by CDF. Hence, the sample size for the study was obtained using the following formula provided by Yamane (1967) as cited in Krejcie \& Morgan (1970). The following formula developed by Yamane (1967) was used to determine the sample size for the study;

$n=\mathrm{N} /\left(1+\mathrm{N}\left(\mathrm{e}^{2}\right)\right)$

$n=172 /\left(1+172\left(0.05^{2}\right)\right)=120$

This yields a sample size of , $\boldsymbol{n}^{\text {"e }} 120$

The sample consisting of $120 n$ respondents was then distributed as shown in table 1.

Table 1: Sample Frame

\begin{tabular}{|l|c|c|}
\hline No. & Department & Population $(N)$ \\
\hline 1. & Education & 60 \\
\hline 2. & Health & 30 \\
\hline 3. & Roads & 30 \\
\hline & Total & $\mathbf{1 2 0}$ \\
\hline
\end{tabular}

\subsection{Data Collection Instrument and Data Procedure}

Primary data was collected using structured questionnaires which were self administered to the sample chosen from all the CDF funded project committees. This is because questionnaire provides a high degree of data standardization and adoption of generalized information amongst any population (Chandron, 2003).

\subsection{Pilot Test}

The questionnaire was pretested to ascertain the reliability of the tool before the actual administration. Pretesting was done by administering the questionnaire to five respondents who were selected outside the sample members of the population. This enabled the researcher to fine tune the questionnaire for validity and reliability. According to (Kimberlin \&Winterstein, 2008), a valid instrument is that which measure what it purports to measure To guarantee validity, the researcher conducted a face and content validity test on the measuring instrument, and had the test reviewed by the faculty and obtain feedback. This was done to ensure that the objectives are clearly defined and operationalized. To ensure reliability of the measuring instrument, careful wording, format and content was used. In this study, the Cronbach alpha $(\alpha)$ with a reliability threshold of $(\alpha \geq 0.7)$ for each variable was attained from the test for internal consistency of the questionnaire.

Table 2: Reliability Statistics

\begin{tabular}{|lc|l|}
\hline Construct & Cronbach's Alpha & N of Items \\
\hline Open tendering method & .785 & 5 \\
Restricted tendering method & .761 & 5 \\
Direct tendering method & .738 & 5 \\
Successful Implementation & .804 & 5 \\
\hline
\end{tabular}

\subsection{Data Collection Procedure}

The researcher sought permission and guidance from the relevant authorities on the appropriate approach to data collection. The researcher then administered the data collection instruments by reaching out to the respondents to fill in the questionnaires. The descriptive survey, using a structured questionnaire and an interview schedule were administered on the selected sample. This method was considered to be more suitable with this kind of research design and sample. The researcher also utilized journals, magazines, and use of internet in collection of data.

\subsection{Data Processing and Analysis}

The collected data was first checked for completeness and comprehensibility. The data was analyzed using SPSS version 20. Both inferential statistics (Pearson correlation) and descriptive statistics (mean, frequencies, percentages and standard deviation) were used. Correlation analysis was used to test the relationship between green human resource management practices and environmental sustainability. The research findings were then presented using tables whose interpretation guided conclusions and recommendations. 


\section{International Journal of Science and Research (IJSR) \\ ISSN (Online): 2319-7064}

Index Copernicus Value (2013): 6.14 | Impact Factor (2015): 6.391

\section{Research Findings}

\subsection{Relationship between Open Tendering and Successful Implementation of CDF Projects}

Table 3: Relationship between Open Tendering and Successful Implementation of CDF Projects

\begin{tabular}{|l|l|l|}
\hline \multicolumn{2}{|c|}{} & \multicolumn{1}{|c|}{$\begin{array}{c}\text { Successful } \\
\text { Implementation }\end{array}$} \\
\hline $\begin{array}{l}\text { Open } \\
\text { Tendering } \\
\text { Method }\end{array}$ & Pearson Correlation & $380^{* *}$ \\
\cline { 2 - 3 } & Sig. (1-tailed) & .000 \\
\cline { 2 - 2 } & $\mathrm{N}$ & 120 \\
\hline$* *$ Correlation is significant at the 0.01 level (1-tailed). \\
\hline
\end{tabular}

The study revealed (Table 3 ) that the relationship between open tendering and successful implementation of CDF projects was positive, weak and statistically $(\mathrm{r}=0.380$; $\mathrm{p}<$ 0.01). This implies the relatively low confidence in the open tendering process for the CDF projects in Njoro sub-county, Nakuru.

\subsection{Relationship between Restricted Tendering and Successful}

Table 4: Correlation between restricted tendering method and successful Implementation Implementation of CDF Projects

\begin{tabular}{|l|l|c|}
\hline \multicolumn{2}{|c|}{} & \multicolumn{1}{c|}{$\begin{array}{c}\text { Successful } \\
\text { Implementation }\end{array}$} \\
\hline \multirow{2}{*}{$\begin{array}{l}\text { Restricted } \\
\text { Tendering } \\
\text { Method }\end{array}$} & Pearson Correlation & $.605^{* *}$ \\
\cline { 2 - 3 } & Sig. (1-tailed) & .000 \\
\cline { 2 - 3 } & $\mathrm{N}$ & 120 \\
\hline \multirow{2}{*}{ **. Correlation is significant at the 0.01 level (1-tailed). } \\
\hline
\end{tabular}

The study revealed (Table 4) that the relationship between restricted tendering and successful implementation of CDF projects was positive and strong $(r=0.605$; $\mathrm{p}<0.01)$ meaning that the success of implementation of CDF projects in Njoro sub-county is highly likely.

\subsection{Relationship between Direct Tendering and Successful Implementation of CDF Projects}

Table 5: Correlation between Direct tendering method and successful Implementation

\begin{tabular}{|l|l|r|}
\hline \multicolumn{2}{|c|}{} & Successful Implementation \\
\hline Direct & Pearson Correlation & $.650^{* *}$ \\
\cline { 2 - 3 } $\begin{array}{l}\text { Tendering } \\
\text { Method }\end{array}$ & Sig. (1-tailed) & .000 \\
\cline { 2 - 3 } & $\mathrm{N}$ & 120 \\
\hline \multirow{2}{*}{$*$. Correlation is significant at the 0.01 level (1-tailed). } \\
\hline
\end{tabular}

The study revealed that the relationship between direct tendering and successful implementation of CDF projects was positive and strong $(r=0.650 ; p<0.01)$. This implies that the direct tendering process influenced the success of implementation of CDF projects in Njoro Sub-county.

\section{Conclusion and Recommendations}

\subsection{Conclusion}

In view of the findings of this study the following conclusions are deduced from the study:

There are various factors affecting project implementation success emanating from procurement selection criteria, tendering methods and variation order factors. Cost, time and quality procurement related selective factors have demonstrated strong conditions for selection of any procurement method and have also influenced the performance of such government projects. The way a project is tendered for can affect its implementation and consequently its performance. Several approaches of tendering allowing new comers, selecting from existing performing vendors and approaches allowing contractors to compete with each other have resulted in successful construction projects. Variation orders have impacted project performance in various ways. It has caused construction projects to have time and cost growths and serious disputes have resulted between parties to contracts. The department complies with all the above legislation and keeps the rules as stipulated in the legislation. This implies there may be a lack of flexibility in part of department as far as tender process is concern. Majority of the respondents strongly believe that there is a there is a need to issue a single national legislative framework in terms to guide uniformity in tendering process.

The study revealed that the tendering legislations and its associated regulations are complex and may make it difficult to implement correctly. The study also revealed that the department complies with all the above legislation and keep the rules as stipulated in the legislation. This implies there may be a lack of flexibility in part of departments as far as tendering process is concerned.

\subsection{Recommendations}

Recommendations based on the study findings include: clients, stakeholders, practitioners as well as consultants on projects should give careful consideration to the tendering method to be adopted when selecting a procurement method and when project is on-going, clients should order fewer variations on the project as this can affect the success of its implementation and avoid misuse of funds for the projects. Restricted, open and directed tendering methods are recommended to clients, consultants and practitioners for use in their project bidding as these methods are known to give successful projects. Policy makers in government, clients, and private developers into funded projects should give adequate attention for selecting appropriate procurement and tendering methods for better management and successful implementation of future projects in Njoro Sub County and other Sub Counties.

Also, the National treasury as the custodian of tendering legislation should consolidate all the different tendering prescript and issues a single national framework. Accounting Officers in the Sub County as head of the department should 


\section{International Journal of Science and Research (IJSR) \\ ISSN (Online): 2319-7064}

Index Copernicus Value (2013): 6.14 | Impact Factor (2015): 6.391

review the effectiveness of the system for monitoring compliance with laws and regulations and the results of managementes investigation and follow up (including disciplinary action) of any instances of non-compliance; review the findings of any examinations by regulatory agencies and any auditor observations related to tendering process; and obtain regular updates from department's legal counsel regarding compliance matter related to tendering process. Accounting officers should, whilst setting standards and assigning responsibilities, promote the development of a tendering process management system that conforms to all regulations or directives as might be applicable.

Instead of being biased towards the lowest price, the direct criteria should include quality, time, delivery, service, flexibility, financial status, capabilities, ethics, and social responsibility. And adequate influence should be placed. The procurement and provisioning procedures in government are overly rule driven, where value for money is almost always equated to the lowest price tendered. The emphasis is almost exclusively focused on the monitoring of inputs, with little or no regard to the outcomes of tendering processes. National government should replace the current outdated tendering practices in government with a tendering process management function and a systematic competitive procedure as an integral part of financial management in government that conforms to internationally accepted best practice principles.

It is clear from the responses that the current tender process activities are executed almost as standalone processes, where there is little or no linkage to budgetary planning. As result the study recommend that both budgetary and tender process should interface in order to avoid unauthorized expenditure and delay in tendering of goods. It is also very important that department should have full details of all tendering process. This includes keeping a record of all documentations for period of five years or more. Electronic record management can also assist to improve the situation. In name of encouraging competitiveness, the procurement department should provide all prospective bidders with timely and adequate notification of an institution "s requirements and an equal opportunity to bid for the required goods, works or services. The department should be mindful of competitive business practices are regulated by the Competition Act, in all its tendering activities.

Furthermore, local government should consider the use negotiation only in exceptional circumstances; it should not preclude competition. In tendering system, all parties should be required to comply with the highest ethical standards to promote mutual trust and respect; and an environment where business can be conducted in a fair and reasonable manner and with integrity. National government in dealing with suppliers and potential suppliers, should, be fair, efficient, firm and courteous at all times. All prospective bidders should be provided the same information and should be assured of equal opportunities to obtain additional information on a timely basis.

\section{References}

[1] Adedokun, O. A., Ibironke, O., Babatunde, S. O. (2013). Assessment of competitive tendering methods of procuring educational building projects in Nigeria. Journal of Facilities Management, Vol. 11(1), pp.81 - 94

[2] Caldwell, N.D. Roehrich, J.K. \& Davies, A.C. (2009). Procuring complex performance in construction: London Heathrow Terminal 5 and a private finance initiative Hospital. Journal of Purchasing and Supply Management15 (3):178-186.

[3] Chinyio, E. (2011). The Cost of Tendering. Working Paper Proceedings. Engineering Project Organizations Conference. Estes Park. Colorado.

[4] Cooper, D. R \& Schindler, P.S (2006). "Business Research Methods", 9th, Ed. McGraw-Hill Publishing, Co. Ltd. New Delhi

[5] Government of Liberia, Ministryb of Finance and Development Planning. (2015). Strategic Plan 20152018. 42-45.

[6] Jerry O. ( 2006). "The Beauty and Shame of Kenya's Constituency Development Fund - CDF". Afroarticles.com. Retrieved 1 June 2010.

[7] Krejcie \& Morgan, (1970). Determining sample size for research activities in education and psychological measurements, pp 30 (33).

[8] Lewis, M.A. \& Roehrich, J.K. (2009). Contracts, relationships and integration: Towards a model of the procurement of complex performance. International Journal of Procurement Management, 2(2):125-142.

[9] Mohammed, R., Hamdan, A. R., Othman, Z. A. \& Noor, N. M. M. (2010). Decision Support Systems (DSS) in Construction Tendering Processes. International Journal of Computer Science. Vol. 7(2), pp. 35-46.

[10] Mungai, P. M. (2014). Influence of Supplier appraisal on Procurement Performance in the Real Estate Industry in Kenya: A Case Study of International House Ltd. International Journal of Operations and Logistics Management, Vo 3 (3) pp. 250-262.

[11] Nick, L. L., Chiu, D. K. W., \& Hung, C. K. (2007). Tendering Process Model (TPM) Implementation for B2B Integration in a Web Services Environment. Proceedings of the 40th Hawaii International Conference on System Sciences.

[12] Oyugi, N.L. (2006) Equity in Resource Allocation: The Need for Alternative Constituency

[13] Development Fund Allocation Criteria (Vol. 76). Nairobi: Institute for Policy Analysis and Research

[14] Prahalad, C.K., and Hamel, G. 1990. The Core Competence of the Corporation. Harvard Business Review, Vol. 68 (3), pp. 79-91.

[15] RoK. (2012) County Procurement Plan, Jomo Kenyatta Foundation, Nairobi, Kenya.

[16] Wamae, J. W. (2014). Role of Procurement Function in Enhancing Performance in Devolved Government: A case of Machakos County. International Journal of Social Sciences and Entrepreneurship, 168-190.

[17] Waara F. (2007), Mitigating Contractual Hazards in Public Procurement, a study of Swedish local authorities. Journal of Construction Management and Economics. Vol. 26,no 1-3, Pg 237145. 
[18] Weele, Arjan J. van (2010). Purchasing and Supply Chain Management: Analysis, Strategy, Planning and Practice (5th ed. ed.). Andover: Cengage Learning. ISBN 978-1-40801896-5.

[19] Williamson, O. (1979a) 'Transaction-cost economics: The governance of contractual relations', Journal of Law and Economics, 22:233-261. 